\title{
CEREBROSPINAL FLUID AND SERUM ANTIPHOSPHOLIPID ANTIBODIES IN MULTIPLE SCLEROSIS, GUILLAIN-BARRÉ SYNDROME AND SYSTEMIC LUPUS ARYTHEMATOSUS
}

\author{
PAULO E. MARCHIORI - MARISA DOS REIS - MARIA E. Z. QUEVEDO \\ D. CALLEGARO - M. TERESA A. HIRATA - M. SCAFF - R. MANOEL DE OLIVEIRA
}

\begin{abstract}
SUMMARY - Immuneglobulins isotypes (IgG and IgM) for myelin basic protein (MRP), cerebrosides (CER), gangliosides (GANG) and cardiolipin (CARD) were detected in the cerebrospinal fluid (CSF) from 33 patients with multiple sclerosis (MS), 18 with Guillain-Barré syndrome (GBS) and 30 with systemic lupus erythematosus (SIE). In MS patients occurred positive and significant levels of IgG-MBF in $51,5 \%(\mathrm{p}<0.05)$ and IgM-MBP in only $18.2 \%$, IgG-CARD in $46.2 \%$, as long as CER and GANG were detected in almost $20 \%$. From serum samples of MS patients $20.6 \%$ presented IgG-MRP, while 53\% showed positive levels for IgM-MBP. The CSF analysis of patients with GBS showed that 56.3\% revealed IgG-MBP $(\mathrm{p}<0.05), 53 \%$ for IgM-MBP, $385 \%$ for IgG-CER and $23 \%$ for IgM-CER, while $50 \%$ of patients had IgG-CARD, as long as $31 \%$ also had IgG-GANG. The serum evaluation from 14 patients showed that $18.8 \%$ had positive concentrations of IgG-MBP and $56.3 \%$ presented IgM-MBP $(p<0.05)$ Except for 50\% of patlents with SLE who presented positive CSF levels of IgG-CARD, only $24.5 \%$ had positive levels of IgG-MLBP. We believe that the presence of antiphosvhohpia antibodies in CSF of the above mentioned diseases occurred as immune epiphenomena, but their appearance would permit the maintenance of and perpetuate the immune event.
\end{abstract}

Anticorpos antifosfolípides no líqüido cefalorraquidiano e no soro em esclerose múltipla, síndrome de Guillain-Barrẻ e lúpus exitematoso sistêmico.

RESUMO - Isotipos de imunoglobulinas (IgG e IgM) de proteina básica de mielina (PBM), cerebrosideos (CER), gangliosideos (GANG) e cardiolipina (CAFD) foram investigados em amostras de líquỉido cefalorraquidiano (LCR) de 33 pacientes com esclerose múltipla (EM), 18 com sindrome de Guillain-Barré (SGB), e 30 com lúpus eritematoso sistêmico (LES). Pacientes com EM revelaram concentracōes positivas e significantes para IgG-PBM em 51,5\% (p<0,05), IgM-PBM em 18,2\%, IgG-CARD em 46,2\%; CER e GANG foram detectados em cerca de $20 \%$ dos pacientes. A avaliacáo dos isotjpos te imunoglobulinas no soro de pacientes com EM foi positiva em 20,6\% para IgG-PBM e 53,0\% para IgM-PBM. No LCR dos pacientes com SGB a análise mostrou-se positiva em 56,3\% para IgG-PBM $(\mathrm{p}<0,05)$, 53\% para IgM-PBM, 38,5\% para lgG-CJR e 23\% para IgM-CER, 50\% para IgG-CARD $\theta$ $31 \%$ para IgM-GANG. Os isotipos avaliados no soro de 14 pacientes com SGB foram positivos em $18,8 \%$ para IgG-PBM e 56,3\% para IgM-PBM $(\mathrm{p}<0,05)$. No ICK, 50\% dos pacientes com LES revelaram positividade para IgG-CARD e 24,1\% para IgG-PBM. Os autores acreditam que a presença de anticorpos antifusfolipides séja conseqüente a epifenômeno imune, embora sua presença possa manter e perpetuar o evento imune intrinseco a essas doenças.

Division of Neurology and Medical Investigation Laboratories, São Paulo University Medical School.

Dr. Paulo E. Marchiori - Clinica Neurologica, Hospital das Climicas - Caixa Postal 3461

01051 São Paulo SP - Brasil. 
Autoimmune involvement has been demonstrated in several neurological diseases 2,4,6,9,10. Humoral and cellular dysfunctions have been studied, and both can act as a primary event and also can represent an epiphenomenon in several diseases $3,7,8$. The presence of phospholipid and their distribution in cellular membranes lead in some occasions to the production of antiphospholipid antibodies (APHA)7. To investigate whether APHA play any important pathogenetic role in multiple sclerosis (MS), Guillain-Barré syndrome (GBS) and systemic lupus erythematosus (SLE), samples of cerebrospinal fluid (CSF) and serum were studied. All specimens were screened by enzymeimmunoassay (ELISA) for determination of $\operatorname{lgG}$ and $\lg M$ immuneglobulin isotypes reacting against myelin basic protein (MBP), cerebrosides (CER), gangliosides (GANG) and cardiolipin (CARD).

\section{CASUISTICS AND METHODS}

Classes of IgG and IgM antibodies to MBP, CER, GANG and CARD were determined in 181 samples of CSF obtained from 33 patients with MS (average age $30.11 \pm 11.90$ years), 18 patients with GBS $(24.26+15.36$ years) 4 of them presenting chronic polyradiculoneuritis, and 30 with SLE $(27,11 \pm 9,29$ years). Serum samples from 48 patients were analysed: 34 with MS and 14 with GBS. Control samples were CSF specimens without detectable alterations from 30 patients with epilepsies or headache. ELISA was used throughuut.

\section{RESULTS}

CSF positive values (Table 1) in MS patients were: 17 (51.5\%) for IgG-MBP, averaging $20.2+28.5 \mathrm{U}(\mathrm{p}<0.05) ; 5(18.2 \%)$ for IgM-MBP with average of $21.7+38.4 \mathrm{U} ; 3$ (17.7\%) for IgG-CER; $2(11,8 \%)$ for IgIM-CER; $5(19.2 \%)$ for IgG-GANG; 2 (7.7\%) for IgM-GANG; 15 (46.2\%) for IgG-CARD; 2 (6\%) for IgM-CARD. In GBS positive values verified were: IgG-MBP in 9 out of $22(56.3 \%)$ with $41.3 \pm 4.4$ U average $(\mathrm{p}<0.05)$; $53 \%$ for IgM-BMP; 5 out of $13(38.5 \%)$ for IgG-CER with $34.40+36.88$ U average; 3 (23.0\%) for IgM-CER, average $6.0+7.0 \mathrm{U}$; $31 \%$ for IgG-GANG; $50 \%$ patients had IgG-CARD, average of $2.7 \pm 1.2 \mathrm{U}$; IgM-CARD occurred in only one patient. In SLE, IgG-MBP occurred in 7 out of 29 (24.1\%) patients, IgM-MBP in $2(7.0 \%)$, IgG-CER in only one patient with no positive for IgM; IgG-GANG in two with none for IgM; IgG-CARD in 5 out of 10 (50\%) with no patients showing positive values for IgM (Figs. 1 and 2). Among controls, APHA positive levels in CSF were detected in only one patient.

The study of serum APHA (Takle 2) showed in MS: IgG-MBP in 7 out 34 (20.6\%) with $4.42 \pm 3.55 \mathrm{U}$ average; IgM-MBP in $18(53.0 \%)$, average $15.1+15.6 \mathrm{U}$; IgG-CER in 4 $(11.8 \%)$ and IgM-CER in 12 out $29(41.4 \%)$; IgG-GANG was found in two patients and 6 showed positive values for IgM-GANG. Three GBS patients showed positive values for IgM-MBP and 9 out $16(56.3 \%)$ for IgM-MBP with average levels of $9.0 \pm 4.0 \mathrm{U}$; IgG-CER was detected in only one case, and $5(31.3 \%)$ presented positive values for IgM-CER; no positive value for IgG-GANG was observed, and 4 (30.8\%) showed positive values for I $M$ M-GANG (Figs. 1 and 2 ).

Positive values of APHA levels (\%)

\begin{tabular}{|c|c|c|c|c|c|c|c|c|}
\hline \multirow[b]{2}{*}{ Disease } & \multicolumn{2}{|c|}{ MBP } & \multicolumn{2}{|c|}{ CER } & \multicolumn{2}{|c|}{ GANG } & \multicolumn{2}{|c|}{ CARD } \\
\hline & IgG & $\operatorname{Ig} M$ & IgG & $\operatorname{Ig} M$ & IgG & $\operatorname{Ig} M$ & IgG & $\operatorname{Ig} M$ \\
\hline MS & 51.5 & 18.2 & 17.7 & 11.8 & 19.2 & 7.7 & 46.2 & 6.0 \\
\hline GBS & 56.3 & 53.0 & 38.5 & 23.0 & 31.0 & & 50.0 & \\
\hline SLE & 24.1 & 7.0 & & & & & 50.0 & \\
\hline
\end{tabular}

Table 1 - APHA in CSF. APHA, antiphospholipid antibodies; $M B P$, myelin basic protein; $C E R$, cerebrosides; GANG, gangliosides; CARD, cardiolipin; $M S$, multiple sclerasis; GBS, Guillain-Barre syndrome; $S L E$, systemic lupus erythematosus. 
Positive values of APHA leveIs

\begin{tabular}{|c|c|c|c|c|c|c|c|c|}
\hline \multirow[b]{2}{*}{ Disease } & \multicolumn{2}{|c|}{ MBP } & \multicolumn{2}{|c|}{ CER } & \multicolumn{2}{|c|}{ GANG } & \multicolumn{2}{|c|}{ CARD } \\
\hline & IgG & IgM & IgG & IgM & IgG & IgM & IgG & $\operatorname{IgM}$ \\
\hline MS & 20.6 & 53.0 & 11.8 & 41.4 & $\mathrm{n}=\mathbf{2}$ * & $\mathrm{n}=\mathbf{6}^{*}$ & ND & ND \\
\hline GBS & 18.8 & 56.3 & $\mathrm{n}=1 *$ & 31.3 & & 30.8 & ND & ND \\
\hline
\end{tabular}

Table 2-APHA in serum. Positive values in \% except for cases number ( $n \Rightarrow$ indicated (*). ND, non determined. See table 1.

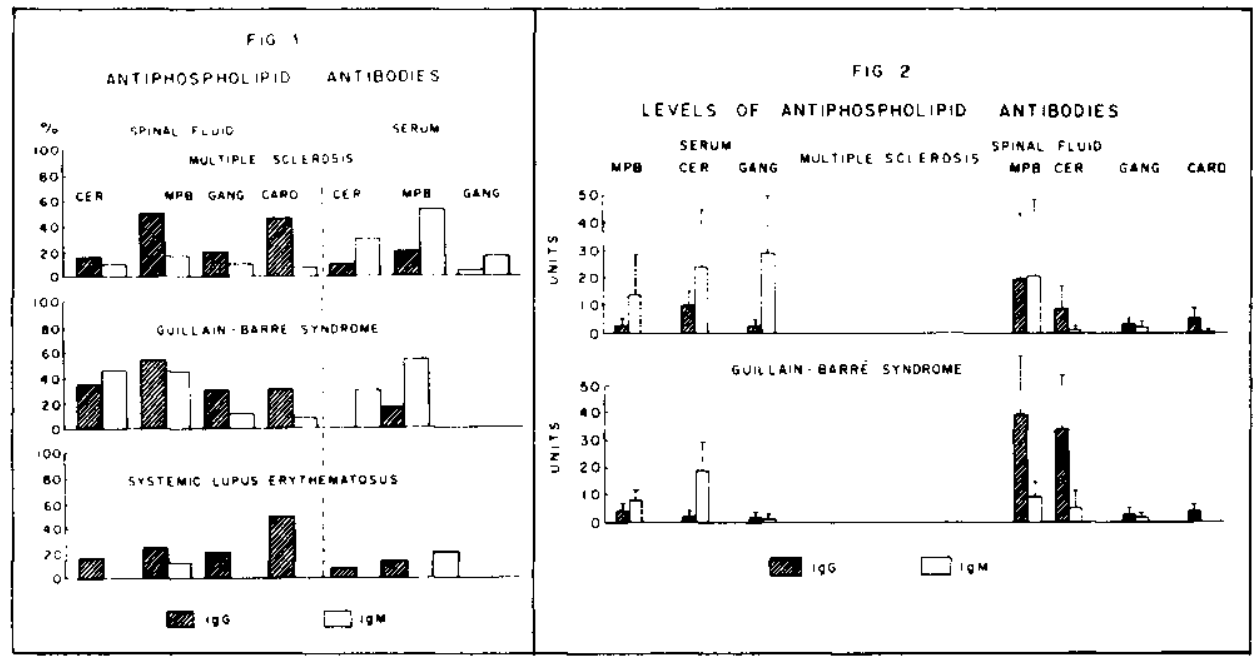

Fig. 1 - Frequency of immuneglobulin isotypes ( $G$ and $M$ ) for antiphospholipid antibodies. $C E R$, cerebrosides; $M B P$, myelin basic protein; GANG, gangliosides; CARD, cardiolipin.

Fig. 2 - Only positive results are represented. Tests were made by ELISA (O.D. $\times 100)$. See Fig. 1 .

\section{COMMFN'TS}

The results herein described suggest APHA in jmmune diseases of the nervous system occurring as immune epiphenomenon. There are few specificity and sensibility for immuneglobulin isotypes of MBP, CER, GANG and CARD from MS and GBS. Significant levels were showed for IgG-MBP and IgG-CARD from MS, IgG-CARD for GBS and SLE, and IgG-CER for GBS.CSF levels can permit evaluation on the maintenance and progression of those immune diseases.

The IgM isotype of MBP and CER occurred in higher frequency in the serum than CSF, although IgG also was obtained, pointing to the extent of the systemic immune alterations in MS and GBS without clinical repercussion. Independent production of these antibodies in the nervous system and in the general immune system can occur. It is possible that the presence of IgG class antibodies in CSF is a consequence of a non-specific aggression of nervous system by antigens. Despite the initial production of non-specific IgG class of antibodies in nervous system, in the following stage it can allow the maintenance of the immune mediated diseases of the nervous system. Among maintenance paths are the presence of complement capacity fixation by IgG, modifications of cellular immune response, essentially lymphocytes phospholipid fragments interations, mainly $M B P$ in $M S$ and CER in GBS. Also presence of cross-reaction among nervous system antigens and the immune cellular membrane, and the trigger of external antigens evidencing the presence of antigens homologies spreadly distributed in the most different tissues and in the nature 11,12 . 


\section{REFERENCES}

1. Alving $\mathrm{CR}$ - Natural antibodies against phospholipids and liposomes in humans. Blochem Soc Trans 12:342, 1984.

2. Arnon R, Crisp E, Helley R, Ellison GW, Myers LW, Tourtellotte WW - Anti-ganglioside antibudies in multiple sclerosis. J Neurol Sci $46: 179,1980$.

3. Cohen O, Schwartz M. Cohen IR, Sela B, Eshhar N - Multiple sclerosis-like disease induced in rabbits by immunization with brain gangliosides. Isr J Med Sci 17:711, 1981.

4. Colaco $\mathbf{C B}$, Scadding GK, Lockhart B - Anti-cardiolipin antibodies in neurological disorders: crosis-reaction with anti-single stranded DNA activity. Clin Exp Immunol 68:313, 1987.

5. Endo T, Scott DD, Stewart SS, Kundu SK, Marcus DM - Antibodies to glycosphingolipids in patients with multiple sclerosis and SLE. J Immunol 132:1793, 1984.

6. Harris EN, Englert H, Derve G, Hughes GRV, Gharavi A - Antiphospholipid antibodies in acute Guillain-Barré syndrome. Lancet 2:1361, 1983.

7. Hawada K, Sakurami T, Imura H, Iwamori M, Nabai $Y-$ Antisialo-GM antibody in sera from patients with Graves disease and Hashimoto thyroiditis. Lancet 2:198, 1980.

8. Hirano T, Hashimoto $H$, Shiokawa $Y$, Iwamori M, Nagii $Y$, Kasa M, Ochiai Y, Okumura $\mathrm{K}$ - Antiglycolipid autoantibody detected in the sera from systemic lupus erythematosus patients. J Clin Invest 66:1437, 1980.

9. Ryber B - Multiple specificities of antibrain antibodies in multiple sclerosis and chronic myelopathy. I Neurol Sci $38: 357,1982$.

10. Yokogawa M, Irmas EG, Brady RO - Sphingolipid antibodies in sera of animals and patients with central nervous system lesions. Proc Soc Exp Biol Med 111:350, 1962.

11. Mendonca EC Neto - Estudo dos isotipos e fixaçăo do complemento anti-nRNP e anti-Sm no lúpus eritematoso sistêmico. Tese. Faculdade de Medicina, Universidade de São Paulo. São Paulo, 1988.

12. Paterson PY - Neuroimmunology: an overwiew and personal perspective. In Aarli JA, Behan WMH, Behan PO (eds): Clinical Neuroimmunology. Blackwell, Oxford, 1987 